УДК 657.37

DOI: https://doi.org/10.26642/jen-2019-3(89)-119-128

Л.Г. Ловінська, д.е.н., проф. Науково-дослідний фінансовий інститут ДННУ «Академія фінансового управління»

С.О. Левицька, д.е.н., проф.

О.О. Осадча, д.е.н., доц.

Наџіональний університет водного господарства та природокористування

\title{
Ендаумент в діяльності вітчизняних закладів вищої освіти: практика застосування та обліку
}

\begin{abstract}
У статті розглянуто практику використання коштів ендаументу вітчизняними та закордонними вищими навчальними закладами як альтернативного джерела додаткового фінансування освітньої й наукової діяльності. Визначено основні проблеми нормативного поля $з$ питань залучення ендаументів, відображення в обліку та звітності державних закладів вищої освіти України операцій з коштами «сталого фонду», серед яких: неоднозначність умов користування основним капіталом ендаумент-фонду та пасивними доходами, недостатній розвиток фінансового ринку в намій державі, відсутність належної мотивації для благодійників з точки зору оподаткування операцій з коштами ендаументу та ін. Узагальнено практику управління ендаумент-фондами зарубіжними закладами вищої освіти, серед яких: створення власних органів з управління активами, передача ендаументу Управляючій компанії, комбінований метод. Доведено доцільність активної реалізаџіï успішної міжнародної моделі «потрійноі спіралі» (співпраці закладу вищої освіти з суб'єктами господарської діяльності, державою). Обгрунтовано альтернативні пропозииії щзоо покращзення нормативного регулювання та облікового відображення коштів ендаумент-фондів державними закладами вищої освіти в Украӥні. 3 метою поліпшення освітньо-наукового інституційного середовища запропоновано: розглянути функціонування різних типів $i$ видів ендаумент-фондів (зокрема, «Фонду під спеціальний проект», "Строкового ендавмент-фонду», "Агентського фонду», "Квазіендавментфонду»); внести зміни до Податкового й Бюджетного кодексів Украйни стосовно надання зовнішнім донорам податкових преферениій, державних пільг з метою забезпечення довгострокового використання цільового капіталу; забезпечувати підготовку власних фахівців, які компетентно розпоряджатимуться коштами ендаумент-фонду, а також прозору підзвітність та відкритість благодійного сектору.

Ключові слова: ендаумент-фонд; заклад вищої освіти; основний капітал; бухгалтерський облік; пасивні доходи; фінансові витрати; необмінні операції.
\end{abstract}

Актуальність теми. Задекларований Україною демократичний шлях розвитку, спрямований на формування ефективно-діючої ринкової економіки, ставить перед державними закладами вищої освіти України вимоги щодо максимальної продуктивності в умовах конкурентного середовища. Це, в свою чергу, обумовлює активний пошук закладами як додаткових джерел фінансування освітньо-наукової діяльності, так і альтернативних шляхів досягнення результативності фінансових потоків.

Державні заклади вищої освіти (далі - 3ВО), хоч і залишаються бюджетними установами з ознакою неприбутковості «0014» [1], є господарюючими суб’єктами у сфері надання освітніх послуг, тому не можуть не враховувати як принципів глобалізації, так правил і норм конкуренції на ринку освітніх послуг.

За світовими стандартами рівень державної підтримки освіти в Україні є достатньо високим: частка витрат державного сектору на освіту в середньому за останні п’ять років досягла 7-8 \% ВВП [2]. Однак практично вся сума виділених коштів іде на поточне споживання, а не на розвиток та/або створення інноваційного продукту, проведення наукових досліджень тощо.

Актуальність цього дослідження зумовлена реальним дефіцитом в сучасних умовах коштів на фінансування інноваційних навчальних та наукових проектів державними закладами вищої освіти, відсутністю дієвої практики залучення та реалізації ними коштів ендаумент-фондів.

Аналіз останніх досліджень та публікацій, на які спираються автори. Питаннями функціонування ендаументів у вищій освіті займалися вітчизняні та зарубіжні вчені, зокрема: Хансманн Г., Калхун К., Ньюман Д. [3]; Рябков К., Покідіна В. [4], Шевченко Л. [5], Магута О. [6], Рисін М., Цибульска Ю. [7], Осецький В., Татомир I. [8], Мокін Б., Жилюк Н. [9] та ін.

Процеси формування збалансованої національної економіки, інтеграція вітчизняної вищої освіти в міжнародний освітній простір ставлять нові вимоги до реалізації потенціалу ендаумент-фондів як реального джерела фінансування інноваційних науково-освітніх реформ для ЗВО.

(C) Л.Г. Ловінська, С.О. Левицька, О.О. Осадча, 2019 
Метою статті є узагальнення міжнародного досвіду використання ендаумент-фондів для визначення раціональних альтернативних шляхів їх залучення державними закладами вищої освіти; обгрунтування альтернативних пропозиції щодо покращення нормативного регулювання ендаументу, його ефективного обліково-організаційного забезпечення.

Викладення основного матеріалу. Ендаумент-фонд (англ. endowment) - цільовий фонд, призначений для використання в некомерційних цілях, у формі суми коштів або цінних паперів у безстроковому фонді, що створюється на основі благодійних внесків від донорів [10]. Світова практика використання ендаументфондів - це потужні інструменти фінансування освітніх та наукових інноваційних програм.

Історично батьківщиною ендаументу є США: кожен 3 шести найбільших університетів цієї країни має більший ендаумент, ніж всі канадські університети разом. Так, фонд Гарварда (Harvard University) втричі більший за сукупність усіх канадських фондів, а одна з найбільших пожертв у фонд Гарварда - 400 млн дол. США.

У Канаді найбільший ендаумент-фонд має Торонтський університет, що становить приблизно 2 млрд дол. США, а сукупний розмір трьох наступних у рейтингу університетських фондів дорівнює приблизно 3,5 млрд дол. США [11].

У міжнародній практиці до благодійної підтримки освіти і науки залучені сьогодні: фонди громад; корпоративні й асоційовані фонди; фонди приватних осіб; фонди глобальних національних інтересів (надають підтримку проектам, які впливають на глобальний розвиток); посередницькі фонди тощо [12]. Серед основних завдань ендаументу сьогодні:

- забезпечення стабільності: незважаючи на те, що інвестиційний дохід університетів від ендаументів залежить від багатьох факторів (стану фінансового ринку, обраної закладом інвестиційної стратегії тощо), більшість університетів дотримується певних правил щодо використання коштів ендаумету для сталого їх надходження;

- забезпечення більшої гнучкості в питаннях фінансування: через нестабільну економіко-політичну ситуацію в світі значна кількість університетів суттєво збільшила витрати на допомогу студентам та працівникам вищого навчального закладу [13];

- виважене скорочення попередньо погоджених з благодійником витрат, що фінансуються ендаументфондом: успіх використання благодійних коштів залежить від впевненості щодо такої підтримки як нинішніми, так і наступними поколіннями студентів [14; 15$]$.

Перший ендаумент в Україні було створено Інститутом міжнародних відносин КНУ ім. Т.Г. Шевченка у 2013 році на базі Благодійної організації «Фонд розвитку Інституту міжнародних відносин». Дещо поступається своїми розмірами Фонд розвитку банківської освіти та науки Львівського інституту банківської справи [8]. На жаль, на даний час у фінансовій звітності 3ВО коштів ендаумент-фонду не виявлено (що свідчить про суттєву прогалину у нормативно-обліковому регулюванні ендаумент-фондів). Поряд 3 цим, досить широкої практики набувають кошти цільового зовнішнього фінансування.

Позитивні зрушення варто зауважити у нормативно-правовому забезпеченні етапів створення ендаумент-фондів: певні аспекти цього процесу відображено у Законах України «Про вищу освіту» [16], «Про благодійну діяльність та благодійні організації» [17] та у Податковому кодексі України [18].

Закон України «Про благодійну діяльність та благодійні організації» визначає необхідність використання процентів та дивідендів від управління благодійними ендаументами 3 метою надання благодійної допомоги бенефіціарам (в т. ч. ЗВО), визначеним благодійниками або уповноваженими ними особами, для виконання благодійних програм, спільної благодійної діяльності.

Податковим кодексом України трактуються кошти ендаументу як сума коштів або цінних паперів, що вносяться благодійником у банк або небанківську фінансову установу, завдяки чому набувач благодійної допомоги отримує право на використання процентів або дивідендів, нарахованих на суму такого ендаументу. При цьому такий набувач не має права витрачати або відчужувати основну суму такого ендаументу без згоди благодійника ( п. 170.7 ст. 170 Податкового кодексу України) [18].

У сфері освіти на даний час ендаумент-фонди передбачається створювати лише на рівні вищої освіти: ЗВО можуть створювати стабільні/сталі фонди (ендаументи), що за своєю сутністю є цільовим капіталом неприбуткової організації. Сталий фонд вищого навчального закладу - сума коштів або вартість іншого майна, призначена для інвестування або капіталізації на строк не менше 36 місяців. Пасивні доходи від використання зазначених сум вищим навчальним закладом спрямовуються на здійснення основної статутної діяльності у порядку, визначеному благодійником або уповноваженою ним особою (п. 22 ч. 1 ст. 1 Закону України «Про вищу освіту») [16].

В Україні практика використання сталих фондів на етапі становлення, однак, серед пріоритетів можна окреслити: фінансування інвестиційних освітніх проектів (в т. ч. будівництва й реконструкції інфраструктури навчального процесу, придбання та модернізації обладнання, оновлення бібліотечних фондів); проведення наукових досліджень, створення наукових лабораторій; упровадження освітніх інновацій (інноваційних навчально-наукових програм); залучення науково-педагогічних кадрів, 
матеріальна підтримка студентів та викладачів; покриття витрат на покращення зв'язків із місцевими громадами, на реінвестування - збільшення обсягу ендаументу (до 50 \%) [19].

Для управління ендаументами в системі менеджменту провідних університетів світу виокремлюють три основні підходи.

1. Найбільші університети з великими ендаумент-фондами створюють власні органи з управління активами, зокрема: Опікунська рада (Board of Trustees) здійснює контроль та управління інвестиційною діяльністю фонду, Інвестиційний комітет (Trustee Investment Committee) - встановлює нормативи щодо розміщення активів та призначає професійних менеджерів для управління фондом на постійній основі. Цей метод є найдешевшим, але пов'язаний з досить високою відповідальністю і ризиком [20].

2. Існує практика невеликих університетів перекладати відповідальність з управління ендаументом на третіх осіб - професійних Управляючих компаній. Ними можуть бути: консалтингові компанії, трастфонди, інвестиційні компанії та банки тощо. 3 одного боку, цей підхід потребує значних ресурсів на оплату комісій за обслуговування, з другого - гарантує стабільний дохід за рахунок професійного менеджменту ззовні.

3. Комбінований метод - поєднання попередніх методів, що дозволяє забезпечувати обмежений ризик за умови середніх сукупних витрат на керівництво ендаумент-фондом [21;22].

Практика діяльності професійних Управляючих компаній (для невеликих 3ВО - відділу, групи забезпечення тощо) акцентує увагу на реалізації переваг ендаумент-фонду, серед яких:

- 3 метою досягнення результативності бенефіціар (в т. ч. ЗВО) розпоряджається отриманим капіталом не самостійно, а за допомогою професійної Управляючої компанії;

- отримані ендаумент-кошти не витрачаються відразу, а інвестуються в цінні папери та інші інструменти, що генерують додатковий дохід;

- Управляюча компанія, на відміну від благодійної організації, має недоторканний основний капітал. При цьому в межах угоди між благодійником та бенефіціаром можуть використовуватися тільки відсотки, отримані з основного капіталу;

- Управляюча компанія, бенефіціар зобов'язані надавати благодійнику прозору звітність про рух ендаумент-фонду та його використання;

- діяльність фонду розрахована на довгострокову перспективу;

- $\quad$ дохід від управління ендаумент-фонду може використовуватися тільки на цілі, визначені при створенні фонду [23; 24].

Університети України активно вивчають зарубіжний досвід по залученню та освоєнню коштів ендаумент-фондів. Узагальнення вітчизняної практики організації господарської діяльності ЗВО (в т.ч. за операціями, що мають цільове фінансування) дозволяє систематизувати альтернативну послідовність заходів на етапах залучення та використання ендаумент-фонду:

1. Розробка та ухвалення адміністрацією ЗВО концепції створення фонду: мети, завдань, місії, візії.

2. Реєстрація організації, що управлятиме капіталом: для масштабних ендаумент-фондів, великих закладів-бенефіціарів - Управляючої компанії; для малих та середніх закладів відділу/департаменту/групи забезпечення (далі - відділу управління) ендаумент-фондом.

3. Формування структури органів управління фонду, що буде містити:

А) для Управляючої компанії: загальні збори фонду, затвердження ними Статуту, благодійних програм; визначення персонального кадрового складу; обгрунтування стратегічних напрямів діяльності;

Б) для відділу управління ендаумент-фондом (внутрішнього відділу ЗВО): затвердженя організаційноуправлінської моделі відділу управління (штату працівників, Положення про роботу відділу, його загальної підпорядкованості органам управління закладом тощо).

4. Розробка та затвердження внутрішніх розпорядчих документів: Кодексу корпоративного управління, Положення про внутрішній контроль та управління ризиками, форм внутрішніх звітів, Кодексу професійної етики, внутрішніх Стандартів якості управління тощо.

5. Визначення першочергової групи донорів (благодійників, меценатів), перспективного плану наповнення ендаумент-фонду. Варто прийняти до уваги міжнародну практику мотивації донорів: фінансові донори, зазвичай, отримують певні нематеріальні вигоди - створення іменних фондів, навчальних аудиторій, стипендіальних програм, грантів, а також пільги на послуги освітньої установи (навчання, проведення конференцій та ін.) [25; 26].

6. Затвердження кошторису використання пасивних доходів від управління активами ендаументу.

7. Прийняття інвестиційних рішень щодо збільшення надходжень за рахунок вкладення коштів у бізнес-проекти.

8. Затвердження внутрішнього Положення щодо системи контролю якості реалізації ендаументкоштів.

Зазначена послідовність заходів враховує вітчизняні особливості нормативного регулювання господарської діяльності, зокрема, проблеми практичного залучення ендаументу для ЗВО в Україні: незначну 
кількість фондових бірж, невеликий обсяг їх торгів, недосконалість роботи та низьку довіру до електронної позабіржової торгівлі фінансовими активами, непопулярність державних цінних паперів та ін.

На жаль, сьогодні бажає кращого інвестиційна культура населення нашої держави. За даними інформаційної агенції «BusinessUA» 2016 року населення України у неорганізованих заощадженнях (готівці) зберігає близько 92 млрд доларів США [27]. Залучення, принаймні, частини цих коштів під гарантії їх цільового використання на потреби культурно-освітнього розвитку дозволить вирішувати низку проблем вищої освіти (в тому числі, іiі інноваційних форм - дуальної освіти, освіти впродовж життя тощо).

Серед передумов забезпечення інноваційного розвитку в державі - реалізація успішної міжнародної моделі «потрійної спіралі»: університети-підприємства-держава. Головна ідея цієї моделі полягає в тому, що потенціал для інновацій та економічного розвитку в суспільстві грунтується на визначальній ролі університету та поєднанні університетів, бізнесу і держави з метою створення нових інституційних форм продукування, трансферту та застосування знань [28].

На думку вчених, інституційним ядром моделі «потрійної спіралі» має стати саме «підприємницький університет», що поєднує навчальну і дослідницьку місії традиційного університету з місією генерації інновацій у тісній органічній співпраці з органами державної влади та підприємствами, які є замовниками та співрозробниками таких інновацій.

Авторитет освітнього закладу надає йому можливість одержувати більш лояльні умови використання ендаументу. Доцільно для ЗВО в перспективі створювати інші види ендаумент-фондів (з відповідним нормативним урегулюванням на державному рівні), наведені в таблиці 1.

Таблиия 1

Альтернативні види ендаумент-фондів для вітчизняних закладів вищої освіти

\begin{tabular}{|c|c|c|}
\hline $\begin{array}{l}\text { № } \\
\text { 3/ח }\end{array}$ & Ендавмент-фонд & Зміст \\
\hline 1. & Фонд під спеціальний проект & $\begin{array}{l}\text { (Special Purpose Endowment) створюється виключно для реалізації } \\
\text { раніше визначеного проекту, цілі якого можуть установлюватися } \\
\text { благодійником або керівництвом закладу }\end{array}$ \\
\hline 2. & Строковий ендавмент-фонд & $\begin{array}{l}\text { (Term Endowment) передбачає, шо всі кошти або їх частина можуть } \\
\text { бути витраченими тільки після закінчення установленого періоду часу } \\
\text { або настання певних подій (залежно від бажання донорів) }\end{array}$ \\
\hline 2.1 . & $\begin{array}{l}\text { Фонд повного використання } \\
\text { (Capital Depletion) }\end{array}$ & $\begin{array}{l}\text { Передбачає поступове витрачання як пасивних доходів, так і основної } \\
\text { суми ендаументу }\end{array}$ \\
\hline 2.2 . & $\begin{array}{l}\text { Резервний робочий капітал } \\
\text { (Working Capital Reserve) }\end{array}$ & Створюваний під покриття дефіциту оборотного капіталу \\
\hline 3. & Агентський фонд (Agency Funds), & $\begin{array}{l}\text { Фондом управляє спеціальна організація (Управляюча компанія) в } \\
\text { інтересах закладу освіти. Така організація може управляти й іншими } \\
\text { фондами }\end{array}$ \\
\hline 4. & Квазіендавмент-фонд & $\begin{array}{l}\text { Створюється самим університетом із власних коштів під інвестиційні } \\
\text { цілі, але функціонує на засадах ендаументу. Обмеження з боку донорів } \\
\text { відсутні - університет може в будь-який момент прийняти рішення } \\
\text { використати основну суму ендавменту }\end{array}$ \\
\hline
\end{tabular}

Джерело: розроблено автором на основі $[5 ; 6 ; 12]$

Операції господарської діяльності бенефіціара (ЗВО) впливають на методику та організацію бухгалтерського обліку закладу, систему його внутрішнього контролю/внутрішнього аудиту показників результативності використання як зовнішнього цільового фінансування, так і бюджетних асигнувань на розвиток вищої освіти.

Ендаумент як об’єкт обліку - це кошти, майно або майнові права (активи) ЗВО, щодо яких здійснюється довгострокова інвестиційна діяльність (капітальні вкладення) 3 метою поточного використання пасивних доходів від такої діяльності для реалізації благодійної мети, що відповідає основній діяльності власника активів - бенефіціара (тобто, 3ВО) .

Національні стандарти бухгалтерського обліку для державного сектору (що не суперечать Міжнародним стандартам бухгалтерського обліку для державного сектору) визначають такі основні методичні підходи в питаннях обліку пасивних доходів за результатами використання ендаумент-фонду:

1. Пасивні доходи залежно від характеру їх походження визнаються доходами відповідно до п. 2.7. НПСБОДС 124 «Доходи» в такому порядку: відсотки - у тому звітному періоді, до якого вони належать, виходячи з бази їх нарахування та строку користування відповідними активами; роялті - за принципом нарахування згідно з економічним змістом відповідної угоди щодо їх одержання; дивіденди в періоді прийняття рішення про їх виплату. При цьому дохід від пасивних доходів (як необмінних 
операцій) оцінюється у сумі їх нарахування/одержання за винятком суми зобов'язань, обумовлених такою операцією (п. 2.4. НПСБОДС 124) [29].

2. Створення ендаументів та управління ними пов'язано з відповідними витратами, зокрема: витратами на оформлення документів (установчими витратами), нарахуванням заробітної плати залучених працівників, використаними канцелярськими товарами, витратами на підтримку та модернізацію інтернет-сторінки, на проведення рекламної кампанії тощо. При цьому витрати, пов'язані з використанням пасивних доходів (за необмінними операціями), визнаються одночасно з вибуттям таких коштів (активів), що призводить до зменшення майбутніх економічних вигід та/або потенціалу корисності, пов'язаних 3 такою операцією, за умови, що ці витрати можуть бути достовірно оцінені (п. 4. НПСБО 135 «Витрати») [30].

3. Оцінка балансової вартості коштів ендаумент-фонду проводиться за результатами підтвердження: права власності на них закладом (управління ними, ідентифікації ризику та контролю над такими операціями); витрат на створення ендаумент-фонду.

4. Визначення ендаументу в Законі України «Про вищу освіту» дозволяє узагальнити особливості методики бухгалтерського обліку ендаументу 3ВО:

- ендаумент є сталим фондом та обліковується: на рахунках відповідних активів (коштів, необоротних активів тощо) з аналітичним субрахунком - як актив; на рахунку «цільового фінансування» 3 аналітичним субрахунком - як пасив;

- ендаумент визнається у формі інвестування або капіталізації: відображається в складі відповідного необоротного активу протягом періоду формування фонду та на рахунках довгострокових інвестицій протягом терміну інвестування його з метою одержання пасивних доходів;

- договірні відношення 3 благодійником укладаються закладом на термін, не менший 36 місяців: в обліку такий залучений капітал є довгостроковими зобов’язаннями;

- результати використання пасивних доходів відображаються на рахунках бухгалтерського обліку доходів від необмінних операцій.

5. Статус ЗВО як неприбуткової організації передбачає використання таких коштів в межах окремого попередньо затвердженого кошторису, з відокремленням таких операцій за аналітичними рахунками бухгалтерського обліку від операцій господарської діяльності ЗВО, що мають інше фінансування.

Таблиия 2

Визнання ендаумент-фонду в Балансі ЗВО (Форма N 1-дс)

А) бенефіціар - ЗВО управляє коштами ендаумент-фонду власними силами (иляхом створення окремого відділу):

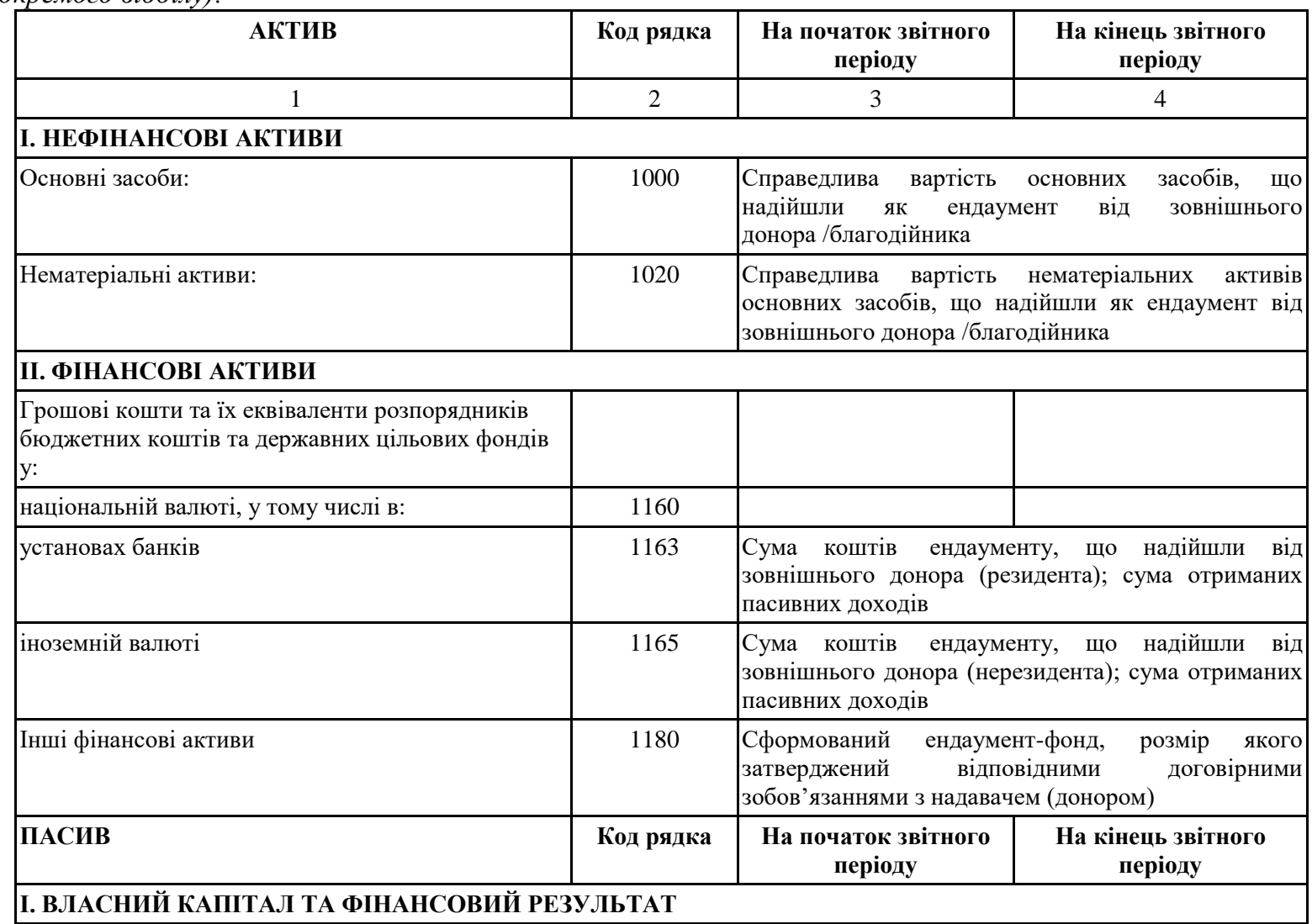




\begin{tabular}{|c|c|c|}
\hline \multirow[t]{2}{*}{ Цільове фінансування } & \multirow[t]{2}{*}{1450} & $\begin{array}{l}\text { Залишки цільового фінансування у формі } \\
\text { ендаумент-фонду як цільового капіталу (одержано } \\
\text { ендаумент-фонд на умовах поступового витрачання } \\
\text { основної суми ендаументу) }\end{array}$ \\
\hline & & $\begin{array}{l}\text { Цільове фінансування у формі отриманих пасивних } \\
\text { доходів }\end{array}$ \\
\hline Усього за розділом I & 1495 & \\
\hline \multicolumn{3}{|l|}{ II. ЗОБОВ'ЯЗАННЯ } \\
\hline \multicolumn{3}{|l|}{ Довгострокові зобов’язання: } \\
\hline інші довгострокові зобов'язання & 1520 & $\begin{array}{l}\text { Довгострокові зобов'язання ЗВО перед надавачем } \\
\text { ендаумент-фонду (одержано ендаумент-фонд на } \\
\text { умовах повернення донору основної суми } \\
\text { ендаументу) }\end{array}$ \\
\hline $\begin{array}{l}\text { Поточна заборгованість за довгостроковими } \\
\text { зобов’язаннями }\end{array}$ & 1530 & $\begin{array}{l}\text { Зарахування довгострокових зобов'язань ЗВО перед } \\
\text { надавачем ендаумент-фонду до поточних, якщо } \\
\text { термін повернення ендаумент-фонду на дату } \\
\text { звітності менше, ніж } 12 \text { місяців }\end{array}$ \\
\hline
\end{tabular}

*дискусійним в нормативному законодавстві залишасться право власності на ендаумент-фонд. У цьому випадку (як альтернатива) - право власності, як і зобов'язання щодо цілісності суми ендаумент-фонду розглянуто за бенефіціаром - ЗВО

Б) бенефіціар - ЗВО передав кочти ендаумент-фонду Управляючій компанії (професійній фінансовій установі) для забезпечення управління ними:

\begin{tabular}{|c|c|c|c|}
\hline АКТИВ & Код рядка & $\begin{array}{c}\text { На початок звітного } \\
\text { періоду }\end{array}$ & $\begin{array}{c}\text { На кінець звітного } \\
\text { періоду }\end{array}$ \\
\hline 1 & 2 & 3 & 4 \\
\hline \multicolumn{4}{|l|}{ I. НЕФІНАНСОВІ АКТИВИ } \\
\hline Основні засоби: & 1000 & \multicolumn{2}{|c|}{$\begin{array}{l}\text { Справедлива вартість основних засобів, що надійшли } \\
\text { як ендаумент від зовнішнього донора (до передачі } \\
\text { Управляючій компанії) }\end{array}$} \\
\hline Нематеріальні активи: & 1020 & \multicolumn{2}{|c|}{$\begin{array}{l}\text { Справедлива вартість нематеріальних активів } \\
\text { основних засобів, що надійшли як ендаумент від } \\
\text { зовнішнього донора (до передачі Управляючій } \\
\text { компанії) }\end{array}$} \\
\hline Усього за розділом I & 1095 & & \\
\hline \multicolumn{4}{|l|}{ II. ФІНАНСОВІ АКТИВИ } \\
\hline \multicolumn{4}{|c|}{$\begin{array}{l}\text { Грошові кошти та їх еквіваленти розпорядників } \\
\text { бюджетних коштів та державних цільових фондів } \\
\text { у: }\end{array}$} \\
\hline національній валюті, у тому числі в: & 1160 & & \\
\hline установах банків & 1163 & \multicolumn{2}{|c|}{$\begin{array}{lr}\text { Сума коштів } & \text { ендаументу, що надійшли від } \\
\text { зовнішнього } & \text { донора-резидента (до передачі } \\
\text { Управляючій компанії); сума отриманих пасивних } \\
\text { доходів (нарахованих Управляючою компанією) }\end{array}$} \\
\hline іноземній валюті & 1165 & \multicolumn{2}{|c|}{$\begin{array}{l}\text { Сума коштів ендаументу, що надійшли від } \\
\text { зовнішнього донора-нерезидента (до передачі } \\
\text { Управляючій компанії); сума отриманих пасивних } \\
\text { доходів (нарахованих Управляючою компанією) }\end{array}$} \\
\hline Інші фінансові активи & 1180 & \multicolumn{2}{|c|}{$\begin{array}{l}\text { Заборгованість Управляючої компанії за переданий } \\
\text { йому бенефіціаром/ЗВО ендаумент-фонд }\end{array}$} \\
\hline інші поточні зобов'язання, з них: & 1575 & \multicolumn{2}{|c|}{$\begin{array}{l}\text { Заборгованість Управляючої компанії за нараховані } \\
\text { бенефіціару/ЗВО пасивні доходи (за результатами } \\
\text { використання ендаумент-фонду) }\end{array}$} \\
\hline \multicolumn{4}{|c|}{ І. ВЛАСНИЙ КАПІТАЛ ТА ФІНАНСОВИЙ РЕЗУЛЬТАТ } \\
\hline & & \multicolumn{2}{|c|}{$\begin{array}{l}\text { Ендаумент-фонд як цільовий капітал, переданий } \\
\text { Управляючій компанії }\end{array}$} \\
\hline Цільове фінансування & 1450 & \multicolumn{2}{|c|}{$\begin{array}{l}\text { Одержані/нараховані Управляючою компанією } \\
\text { пасивні доходи за результатами використання } \\
\text { коштів ендаумент-фонду }\end{array}$} \\
\hline
\end{tabular}




\begin{tabular}{|l|l|l|l|}
\hline \multicolumn{2}{|l|}{ II. ЗОБОВ'ЯЗАННЯ } & & \\
\hline Довгострокові зобов'язання: & 1520 & $\begin{array}{l}\text { Довгострокові зобов'язання ЗВО перед надавачем } \\
\text { ендаумент-фонду (благодійником). }\end{array}$ \\
\hline інші довгострокові зобов'язання & 1530 & $\begin{array}{l}\text { Зарахування довгострокових зобов'язань 3ВО перед } \\
\text { надавачем ендаумент-фонду до поточних, якщо } \\
\text { термін повернення коштів на дату звітності менше 12 } \\
\text { місяців }\end{array}$ \\
\hline $\begin{array}{l}\text { Поточна заборгованість за довгостроковими } \\
\text { зобов'язаннями }\end{array}$ \\
\hline
\end{tabular}

Таблиия 3

Визнання пасивних доходів від використання коштів ендаумент-фонду та витрат, на погашення яких вони спрямовуються (відповідно до иільвового призначення ендаументу) в «Звіті про фінансові результати» $3 B O($ Форма $N 2-\partial c)$

\begin{tabular}{|c|c|c|}
\hline Доходи від необмінних операцій & & \\
\hline Інші доходи від необмінних операцій & 2130 & $\begin{array}{l}\text { Пасивні доходи від використання } \\
\text { ендаумент-фонду }\end{array}$ \\
\hline Усього доходів & 2200 & \\
\hline ВИТРАТИ & & \\
\hline Витрати за необмінними операціями & & \\
\hline Інші витрати за необмінними операціями & 2310 & $\begin{array}{l}\text { Витрати операційної діяльності 3ВО, на } \\
\text { покриття яких направлено пасивні доходи } \\
\text { ендаумент-фонду }\end{array}$ \\
\hline Усього витрат & 2380 & \\
\hline
\end{tabular}

\section{Висновки та перспективи подальших досліджень:}

1. Враховуючи спірність та ризикованість упровадження західних моделей класичного (сталого) ендаумент-фонду в Україні, з метою покращення освітньо-наукового інституційного середовища доцільно розглянути функціонування різних типів і видів ендаумент-фондів. У поточній та середньостроковій перспективі державним вищим навчальним закладам варто надати можливість на законодавчому рівні утворювати не тільки «сталий фонд» (ендавмент), але й інші - «Фонд під спеціальний проект», «Строковий ендаумент-фонд», «Агентський фонд», «Квазіендаумент-фонд» на поточну, середньострокову та довгострокову перспективи. Зазначені фонди мають суттєві особливості в джерелах формування, строках і пропорціях використання основного капіталу та інвестиційного пасивного доходу.

2. Очевидною є потреба в імплементації міжнародного досвіду з питань функціонування моделі «потрійної спіралі»: синергетичний ефект посилює заємодія через налагодження ефективної співпраці 3 випускниками, роботодавцями та колишніми працівниками, що перейшли в інші сфери діяльності

3. Актуальним $є$ внесення змін до Податкового й Бюджетного кодексів України стосовно надання зовнішнім донорам податкових преференцій, державних пільг з метою забезпечення довгострокового використання цільового капіталу.

Для прикладу: у США влада штату має право встановлювати пільги для донорів у співвідношенні сум податку на прибуток, що надходять у його бюджет. Крім того, встановлюється ліміт податкового утримання (максимум 500 дол. і не більше від загального розміру податку на доходи, що підлягає сплаті). Власна схема допомоги донорам діє також у Великобританії: бенефіціар-навчальний заклад може отримати сплачену суму податків додатково до отриманого дарування від податкових органів при заповненні податкової декларації [8].

4. На часі - залучення управлінців ЗВО до вирішення таких питань: забезпечення підготовки власних фахівців, які компетентно розпоряджатимуться коштами ендаумент-фонду; забезпечення прозорої підзвітності й відкритості благодійного сектору; запровадження культури благодійності та ефективних механізмів іiі втілення (особливо серед фізичних осіб - благодійників); урахування міжнародного досвіду щодо випуску благодійними фондами власних фінансових продуктів - боргових цінних паперів зі змінною й фіксованою ставками, держателі яких звільняються від податку на прибуток за отриманими доходами, що стимулює до придбання цих паперів тощо.

Зазначені кроки - ще один мотивуючий фактор для посилення іміджу державного закладу вищої освіти: тільки інноваційно-привабливим університетам довірять свої кошти суб'єкти господарювання та фізичні особи-благодійники. В свою чергу, це уможливить покращення рейтингу таких ЗВО, підвищення результативності відповідних показників на етапах освоєння ними бюджетних асигнувань. 
Список використаної літератури:

1. Про затвердження Положення про Реєстр неприбуткових організацій та установ : Наказ Міністерства фінансів України від 24.01.2013 р. № 37 / Міністерство фінансів України [Електронний ресурс]. - Режим доступу : https://zakon.rada.gov.ua/laws/show/440-2016-\%D0\%BF.

2. Про Рекомендації парламентських слухань на тему: «Стратегії інноваційного розвитку України на 2010-2020 роки в умовах глобалізаційних викликів» : Постанова Верховної Ради України від 21.10.2010 р. № 2635-VI / Верховна Рада України [Електронний ресурс]. - Режим доступу : http://kno.rada.gov.ua/uploads/36382.pdf.

3. Лернер Дж. Секрети академії: стимули успіху університетського ендавменту / Дж.Легнер, А. Чор, Дж.Ванг // Журнал економічних перспектив. - 2008. - Вип. 22. - С. 207-222.

4. Рябков K. Ендавмент у вищій освіті: світова практика і українське сьогодення / К.Рябков // Проект «Популярна економіка: ціна держави». - 2015. - № 34. - 18 с. [Електронний ресурс]. - Режим доступу : http:///www.case-ukraine.com.ua/2016/03/endowment_report_2015-11.pdf.

5. Шевченко Л. Ендавмент-фонди в інвестиційній стратегії зарубіжних університетів / Л.Шевченко // Україна: аспекти праці. - 2015. - № 1. - С. 8-16.

6. Магута O.B. Методичні підходи до формування цільового капіталу (ендаументу) для інноватизації вищої освіти в Україні / O.B. Магута // Ефективна економіка. - 2016. - № 6 [Електронний ресурс]. - Режим доступу : http://www.m.nayka.com.ua/?op=1\&j=efektyvna\&s5050.

7. Рисін М.В. Джерела формування капіталу ендавмент-фонду вищого навчального закладу / M.B. Рисін // Економіка та управління національним господарством. - 2015. - Вип. 2 (112). - С. 123-127.

8. Осещький В.Л. Особливості використання ендавменту та фандрейзингу в освітній практиці / В.Л. Осещький, I.Л. Татомир // Фінанси України. - 2016. - Вип. 3. - С. 85-100.

9. Мокін Б. Ендавмент-фонд як альтернативне джерело для підвищення фінансової стійкості вищого навчального закладу / Б.Мокін // Вісник ХНУ. - 2012. - № 2. - С. 131-135.

10. Що таке ендаумент [Електронний ресурс]. - Режим доступу : http://iirfund.org/about/endowment.

11. Ендаумент-фонди освіти США [Електронний ресурс]. - Режим доступу : https://iirfund.org/about/endowment.

12. Facts About College and University Endowments [Електронний ресурс]. - Режим доступу : https://nces.ed.gov/fastfacts/display.asp?id=73.

13. American Council on Education, Understanding College and University Endowments, One Dupont Circle NW, Washington, DC 20036-1193 p. [Electronic resource]. - Access mode : https://accelerator.american.edu/about source=google\&utm_medium campaign.

14. Investment returns and distribution policies of non-profit endowment funds [Electronic resource]. - Access mode : https://editorialexpress.com/cgi-bin/conference_id=1219.

15. The Interaction of Spending Policies, Asset Allocation Strategies, and Investment Performance at University Endowment Funds [Electronic resource]. - Access mode : https://ideas.repec.org/p/nbr/nberwo/19517.html.

16. Про вищу освіту : Закон України від 01.07.2014 p. № 1556-VII [Електронний ресурс]. - Режим доступу : https://zakon.rada.gov.ua/laws/show/1556-18.

17. Про благодійну діяльність та благодійні організації : Закон України від 05.07.2012 p. № 5073-VI / Верховна Рада України [Електронний ресурс]. - Режим доступу : https://zakon.rada.gov.ua/laws/show/5073-17.

18. Податковий кодекс України від 02.12.2010 p. № 2755-VI / Верховна Рада України [Електронний ресурс]. Режим доступу : https://zakon.rada.gov.ua/laws/show/2755-17.

19. Кочин В.В. Поняття і ознаки ендавменту / В.В. Кочин // Університетські наукові записки. - 2018. - № 67-68. C. 34-43 [Електронний ресурс]. - Режим доступу : www.unz.km.ua.

20. Harvard Management Company [Electronic resource]. - Access mode : http://www.hmc.harvard.edu/hmcandharvard/index.html.

21. The endowment model and modern portfolio theory [Electronic resource]. - Access mode : https://www.nber.org/2018LTAM/yang.pdf.

22. Браун К. Розподіл активів і показники портфеля: дані університетського ендавменту / К.Браун, Л.Гарлаппі, К.Т’ю // Журнал фінансових ринків. - 2010. - № 13. - С. 268-294.

23. Дмитришин М.В. Ендавмент вищого навчального закладу / М.В. Дмитрииин // Актуальні проблеми розвитку економіки регіону. Економічний вісник університету. - 2015. - № 34/1. - С. 64-73.

24. The 100 Richest Universities: Their Generosity and Commitment to Research. - 2015 [Electronic resource]. - Access mode : http://www.thebestschools.org/features/richest-universities-endowments-research.

25. Рябков K. Ендавмент у вищій освіті: світова практика і українське сьогодення / К.Рябков // Популярна економіка: ціна держави. - 2015. - № 34 [Електронний ресурс]. - Режим доступу : http://www.caseukraine.com.ua/wp-content/2016/03/endowment_2015-11-20-fi nal1.pdf.

26. Автономія та врядування у вищій освіті : зб. наук. пр. / О.П. Воробйова, К.О. Жданова, І.Б. Зарубінська та ін. ; за ред. С.А. Калашнікової, В.І. Лугового, Ж.В. Таланової. - К. - 2014. - 236 с.

27. Скільки грошей тримають українці «під матрасами» [Електронний ресурс]. - Режим доступу : http://businessua.com/suspilstvo/25432skilki-groshei-trimayut-ukainci.html.

28. Ranga M. Triple Helix Systems: An Analytical Framework for Innovation Policy and Practice in the Knowledge Society Industry and Higher Education / M.Ranga, H.Etzkowitz // Special Issue «Innovation policy as a concept for developing economies: renewed perspectives on the Triple Helix system». 2013. - № 27 (4). - P. 237-262 [Electronic resource]. - Access mode : https://www.academia.edu/4807351_M.2013_Triple_Helix. 
29. Національне положення (стандарт) бухгалтерського обліку в державному секторі 124 «Доходи» : Наказ Міністерства фінансів України від 24.12.2010 № 1629 / [Електронний ресурс]. - Режим доступу : http://www.minfin.gov.ua/control/.

30. Національне положення (стандарт) бухгалтерського обліку в державному секторі 135 «Витрати» : Наказ Міністерства фінансів України від 18.05.2012 № 568 [Електронний ресурс]. - Режим доступу : http://zakon.rada.gov.ua/laws/s/z0903-12.

\section{References:}

1. Ministerstvo Finansiv Ukrainy (2013), Pro Zatverdzhennia Polozhennia Pro Reiestr Neprybutkovykh Orhanizatsii Ta Ustanov, nakaz, No. 37, [Online], available at: https://zakon.rada.gov.ua/laws/show/440-2016-\%D0\%BF.

2. Verkhovna Rada Ukrainy (2010), Pro Rekomendatsii parlamentskykh slukhan na temu: «Stratehii innovatsiinoho rozvytku Ukrainy na 2010-2020 roky v umovakh hlobalizatsiinykh vyklykiv», Postanova, No. 2635-VI, [Online], available at: http: //kno.rada.gov.ua/uploads/36382.pdf

3. Lehner, Dzh., Chor, A. and Vanh, Dzh. (2008), «Sekrety akademii: stymuly uspikhu universytetskoho endavmentu», Zhurnal ekonomichnykh perspektyv, Vol. 22, pp. 207-222.

4. Riabkov, K. (2015), «Endavment u vyshchii osviti: svitova praktyka i ukrainske sohodennia», Proekt «Populiarna ekonomika: tsina derzhavy», No. 34, 18 p., [Online], available at: http:///www.caseukraine.com.ua/2016/03/endowment_report_2015-11.pdf

5. Shevchenko, L. (2015), «Endavment-fondy v investytsiinii stratehii zarubizhnykh universytetiv», Ukraina: aspekty pratsi, No. 1, pp. 8-16.

6. Mahuta, O.V. (2016), «Metodychni pidkhody do formuvannia tsilovoho kapitalu (endaumentu) dlia innovatyzatsii vyshchoi osvity v Ukraini», Efektyvna ekonomika, No. 6, [Online], available at: http://www.m.nayka.com.ua/?op=1\&j=efektyvna\&s5050

7. Rysin, M.V. (2015), «Dzherela formuvannia kapitalu endavment-fondu vyshchoho navchalnoho zakladu», Ekonomika ta upravlinnia natsionalnym hospodarstvom, Vol. 2 (112), pp. 123-127.

8. Osetskyi, V.L. and Tatomyr, I.L. (2016), «Osoblyvosti vykorystannia endavmentu ta fandreizynhu v osvitnii praktytsi», Finansy Ukrainy, Vol. 3, pp.85-100.

9. Mokin, B. (2012), «Endavment-fond yak alternatyvne dzherelo dlia pidvyshchennia finansovoi stiikosti vyshchoho navchalnoho zakladu», Visnyk Khmelnytskoho natsionalnoho universytetu, Vol. 1, pp. 131-135.

10. «Shcho take endaument», [Online], available at: http://iirfund.org/about/endowment

11. «Endaument-fondy osvity SSHA», [Online], available at: https://iirfund.org/about/endowment

12. «Facts About College and University Endowments», [Online], available at: https://nces.ed.gov/fastfacts/display.asp?id=73

13. «American Council on Education, Understanding College and University Endowments, One Dupont Circle NW, Washington, DC 20036-1193 p.», [Online], available at: https://accelerator.american.edu/aboutsource=google\&utm_medium campaign

14. «Investment returns and distribution policies of non-profit endowment funds», [Online], available at: https://editorialexpress.com/cgi-bin/conference_id=1219

15. «The Interaction of Spending Policies, Asset Allocation Strategies, and Investment Performance at University Endowment Funds», [Online], available at: https://ideas.repec.org/p/nbr/nberwo/19517.html

16. Verkhovna Rada Ukrainy (2014), Pro vyshchu osvitu, zakon Ukrainy, No. 1556-VII, [Online], available at: https://zakon.rada.gov.ua/laws/show/1556-18

17. Verkhovna Rada Ukrainy (2012), Pro blahodiinu diialnist ta blahodiini orhanizatsii, zakon Ukrainy, No. 5073-VI, available at: https://zakon.rada.gov.ua/laws/show/5073-17

18. Verkhovna Rada Ukrainy (2010), Podatkovyi kodeks Ukrainy, No. 2755-VI, [Online], available at: https://zakon.rada.gov.ua/laws/show/2755-17

19. Kochyn, V.V. (2018), «Poniattia i oznaky endavmentu», Universytetski naukovi zapysky, No. 67-68, pp. 34-43, [Online], available at: www.unz.km.ua

20. «Harvard Management Company», [Online], available at: http://www.hmc.harvard.edu/hmc-andharvard/index.html

21. «The endowment model and modern portfolio theory», [Online], available at: https://www.nber.org/2018LTAM/yang.pdf

22. Braun, K., Harlappi, L. and Tiu, K. (2010), «Rozpodil aktyviv i pokaznyky portfelia: dani universytetskoho endavmentu», Zhurnal finansovykh rynkiv, Vol. 13, pp. 268-294.

23. Dmytryshyn, M.V. (2015), «Endavment vyshchoho navchalnoho zakladu», Aktualni problemy rozvytku ekonomiky rehionu. Ekonomichnyi visnyk universytetu, No. 34/1, pp. 64-73.

24. «The 100 Richest Universities: Their Generosity and Commitment to Research» (2015), [Online], available at: http://www.thebestschools.org/features/richest-universities-endowments-research

25. Riabkov, K. (2015), «Endavment u vyshchii osviti: svitova praktyka i ukrainske sohodennia», Populiarna ekonomika: tsina derzhavy: proekt, No. 34, [Online], available at: http://www.case-ukraine.com.ua/wpcontent/2016/03/endowment_2015-11-20-fi nal1.pdf

26. Vorobiova, O.P., Zhdanova, K.O. and Zarubinska, I.B. (2014), Avtonomiia ta vriaduvannia u vyshchii osviti, zb. nauk. pr., Kyiv, 236 p.

27. «Skilky hroshei trymaiut ukraintsi «pid matrasamy», [Online], available at: http://businessua.com/suspilstvo/25432skilki-groshei-trimayut-ukainci.html

28. Ranga, M., Etzkowitz, N. (2013), «Triple Helix Systems: An Analytical Framework for Innovation Policy and Practice in the Knowledge Society Industry and Higher Education», Special Issue «Innovation policy as a concept 
for developing economies: renewed perspectives on the Triple Helix system», No. 27 (4), pp. 237-262, [Online], available at: https://www.academia.edu/4807351_M.2013_Triple_Helix

29. Ministerstvo finansiv Ukrainy (2010), Natsionalne polozhennia (standart) bukhhalterskoho obliku v derzhavnomu sektori 124 «Dokhody», nakaz, [Online], available at: http://www.minfin.gov.ua/control/

30. Ministerstvo finansiv Ukrainy (2010), Natsionalne polozhennia (standart) bukhhalterskoho obliku v derzhavnomu sektori 135 «Vytraty», nakaz, [Online], available at: http: //zakon.rada.gov.ua/laws/s/z0903-12

Ловінська Людмила Геннадіївна - доктор економічних наук, професор, заступник директора Науково-дослідного фінансового інституту ДННУ «Академія фінансового управління» 3 наукової роботи.

Наукові інтереси:

- облік, аналіз, контроль господарської діяльності суб' єктів державного сектору в сучасних умовах модернізації бухгалтерського обліку.

Левицька Світлана Олексіївна - доктор економічних наук, професор Національного університету водного господарства та природокористування.

Наукові інтереси:

- обліково-аналітичне забезпечення господарської діяльності вітчизняних суб'єктів в умовах сталого розвитку національної економіки.

Осадча Ольга Олексіївна - доктор економічних наук, доцент Національного університету водного господарства та природокористування.

Наукові інтереси:

- обліково-аналітичне забезпечення господарської діяльності підприємств та бюджетних установ як інструментарій сучасної системи менеджменту їх діяльності.

Стаття надійшла до редакції 11.07.2019. 